\title{
Inhibition of PAR-1 Receptor Signaling by Enoxaparin Reduces Cell Proliferation and Migration in A549 Cells
}

\author{
AZHAAR ALTURKISTANI ${ }^{1}$, NISANNE GHONEM ${ }^{2}$, VERNA-ANN POWER-CHARNITSKY ${ }^{3}$, \\ ALEJANDRO PINO-FIGUEROA ${ }^{1}$ and MATTIA M. MIGLIORE ${ }^{1}$ \\ Department of Pharmaceutical Sciences, ${ }^{1}$ MCPHS University, Boston, MA, U.S.A.; \\ Department of Biomedical and Pharmaceutical Sciences, ${ }^{2}$ University of Rhode Island, Kingston, RI, U.S.A.; \\ Department of STEM, ${ }^{3}$ Regis College, Weston, MA, U.S.A.
}

\begin{abstract}
Background/Aim: Low-molecular weight heparins (LMWHs) may possess putative antitumoral properties; however, the underlying mechanism(s) remains elusive. We evaluated the antiproliferative and antimigratory effects of enoxaparin (a LMWH) in lung adenocarcinoma A549 cells, and assessed the possible mechanism involved, and the effect on doxorubicin's efficacy. Materials and Methods: Proliferation and migration were evaluated using BrdU and transwell assays, respectively. Immunoblotting was used to measure PAR1, PAR-2, MMP-2, ERK1/2 and Akt proteins. Apoptosis and cell cycle studies examined the combined effect of enoxaparin and doxorubicin. Results: Enoxaparin inhibited A549 cell proliferation and migration. Following PAR-1 gene knock down, enoxaparin's effect on A549 cell proliferation was diminished compared to scrambled siRNA. Our experiments verified that enoxaparin-mediated down-regulation of MAPK and PI3K, reduced MMP-2 expression and inhibited A549 cell migration. Additionally, enoxaparin increased doxorubicin's efficacy by enhancing apoptosis, while no effect on cell-cycle progression was observed. Conclusion: Results suggest that the anticancer activity of enoxaparin in A549 cells was mediated by the interference of two major PAR-1 downstream signaling pathways, MAPK/ERK and PI3K/Akt, which in turn inhibit proliferation and migration. Therefore, enoxaparin may be promising as an adjunct to traditional chemotherapy for lung cancer and warrants further investigation.
\end{abstract}

This article is freely accessible online.

Correspondence to: Mattia M. Migliore, MCPHS University, This article is freely accessible online.

Department of Pharmaceutical Sciences, 179 Longwood Avenue, Boston, MA 02115, USA. Tel: +1 6178795924, Fax: +1 6177322228, e-mail: mattia.migliore@mcphs.edu

Key Words: Enoxaparin, lung cancer, proliferation, migration, apoptosis, cell cycle, doxorubicin, protease-activated receptor-1.
Lung cancer is one of the most fatal malignancies in the United States with a higher mortality rate than breast, prostate and colon cancer combined (1). However, lung cancer is a relatively under-studied malignancy with respect to treatment options and improving its prognosis and survival rate. There has been a growing interest in the enhanced clinical outcomes seen among cancer patients taking concomitant low-molecular weight heparin (LMWH) for the management of venous thromboembolism (VTE) alongside standard chemotherapeutic treatments. LMWHs are short chains of polysaccharides, approximately 2-8 $\mathrm{kDa}$, prepared by depolymerization of unfractionated heparin (2). Until recently, LMWHs have been the anticoagulants of choice in cancer patients with acute thrombosis (3). However, data from recent randomized clinical trials comparing two of the new direct oral anticoagulants (DOACs; edoxaban or rivaroxaban) versus LMWHs have shown DOACs to be at least non-inferior to the LMWHs in the treatment of cancer-associated VTE, and this has led to a guidance statements recommending the use of these newer agents only in cancer patients with low bleeding risk (4). Nonetheless, there is controversial data concerning LMWHs' ability to suppress cancer progression, which has hindered their clinical use outside the treatment of VTE, where these agents could potentially provide additional benefit in the form of increased cancer survival and improved clinical outcomes. For this reason, it was imperative to clearly understand the underlying mechanism(s) of the prospective anticancer activities of LMWHs that have been observed in many clinical and preclinical studies (5-8).

Cancer patients are 5-7 times more susceptible to VTE compared to non-cancer patients (9). Investigators have shown a significant association between VTE incidence and higher malignancy (10). This suggests a strong correlation between the hemostatic system and cancer pathophysiology. Although the connection between the two is not fully understood, studies have demonstrated a two-sided interaction, supporting the notion that activation of the blood coagulation pathways may accelerate cancer progression and 
contrariwise. On one hand, tumor cells and their products have the ability to activate the coagulation system and contribute to the acquired hypercoagulable state $(11,12)$. On the other hand, evidence has demonstrated that elevated hemostatic proteases can positively impact tumor progression $(10,13)$. There are several different molecular mechanisms by which these hemostatic components influence tumor biology. Nevertheless, activation of the protease-activated receptors (PARs) appears to be an important mechanism for tumor development and progression (10,13-15).

The PARs belong to a subfamily of the G-protein coupled receptors (GPCRs) and they carry their own ligand that is activated by a serine protease. Activation of PARs trigger different downstream signaling pathways resulting in a variety of cellular responses, including thrombosis, hemostasis, cell survival, proliferation and inflammation (16). Studies have also demonstrated that PARs play a pivotal role in cancer pathophysiology $(14,17)$. Of the four PAR isoforms, PAR-1 and PAR-2 are up-regulated in many human cancers, such as lung, liver, breast, colon, prostate and melanoma (18). Additionally, investigators have shown a strong association between tumor aggressiveness and expression levels of PARs (19-24). As a result of the cancer-associated hypercoagulation, PARs activation by the elevated hemostatic proteases have shown to induce cell growth, proliferation, angiogenesis and metastasis, which subsequently impact tumorigenesis. Based on these findings, we hypothesized that anticoagulant therapies that target and limit those proteases, such as the LMWH enoxaparin, could be a helpful clinical tool to reduce cancer progression and improve prognosis. Clinical studies have shown that LMWHs used for VTE have significantly improved survival rates and clinical outcomes in many malignancies independently of their anticoagulant function $(6$, 25). Furthermore, there are appealing preclinical studies showing that LMWHs exert antitumor effects via multiple mechanisms $(7,8)$. An in vitro study has demonstrated that enoxaparin significantly decreases cell growth, but not cell invasion in primary cell cultures of high-grade gliomas. The antiproliferative effect was more prominent in cultures with higher PAR-1 expression, although no conclusive relationship between PAR-1 and enoxaparin's activity was made (26). Enoxaparin has also been shown to significantly inhibit thrombin-induced osteosarcoma proliferation both in vitro and in vivo (27). Additionally, both enoxaparin and dalteparin can inhibit migration of patients-derived vascular smooth muscle cells (28). Moreover, enoxaparin reduced lung metastasis by $70 \%$ in an experimental mouse model (29).

With the extremely complicated and interactive relationship between the coagulation system and cancer, as well as the unclear mechanisms underlying LMWHs' antitumoral effects, we aimed to investigate the antineoplastic characteristics of enoxaparin, more specifically its antiproliferative and antimigratory effects in the A549 lung adenocarcinoma cell line and delineate the potential molecular mechanisms involved. Furthermore, we assessed enoxaparin's ability to improve doxorubicin's efficacy in A549 and the mechanism(s) involved.

\section{Materials and Methods}

Cell culture and reagents. A549 cell line was purchased from ATCC (Manassas, VA, USA) and maintained in complete Dulbecco's Modified Eagle Medium (DMEM) supplemented with $10 \%$ fetal bovine serum (FBS) and 1\% penicillin-streptomycin antibiotics that were all obtained from ATCC (Manassas, VA, USA). Cells were kept at $37^{\circ} \mathrm{C}$ in a $5 \% \mathrm{CO}_{2}$ incubator. Enoxaparin and doxorubicin were obtained from Cardinal Health (Dublin, OH, USA). Genistein and staurosporine were purchased from Sigma-Aldrich (St. Louis, MO, USA). Human $\alpha$-thrombin was purchased from Haematologic Technologies (Essex, VT, USA). Primary antibodies against PAR1, PAR-2 and thrombin were obtained from Abcam (Cambridge, MA, USA). Antibodies against ERK1/2, p-ERK1/2, Akt, and p-Akt were purchased from Cell Signaling (Danvers, MA, USA). Secondary antibody was obtained from EMD Millipore (Temecula, CA, USA). Gene probes for PAR-1, MMP-1, MMP-2, MMP-3, MMP-9 as well as PAR-1 and scrambled siRNAs were purchased from ThermoFisher (Rockford, IL, USA).

Bromodeoxyuridine $(B r d U)$ cell proliferation assay. Cells were seeded in a 96 -well plate $\left(5 \times 10^{3} /\right.$ well) using complete DMEM and were allowed to attach overnight. Media was then replaced with fresh DMEM supplemented with 5\% FBS and was subsequently treated with enoxaparin or doxorubicin for $24 \mathrm{~h}$. For PAR-1 activation with $\alpha$-thrombin, cells were seeded as previously described and were allowed to attach for $4 \mathrm{~h}$, then media was replaced with fresh serum-free DMEM and cells were subsequently treated with $\alpha$-thrombin for $24 \mathrm{~h}$. BrdU labeling solution was added $1 \mathrm{~h}$ after the treatments. An ELISA BrdU was performed as per the manufacturer's (Roche Diagnostics; Florham Park, NJ, USA) protocol. Absorbance was measured at $450 \mathrm{~nm}$ using microplate reader SYNERGY/HT.

Migration assay. Cell migration was studied using $8 \mu \mathrm{m}$ pore $24-w e l l$ transwell chambers purchased from ThermoFisher. Cell suspension $\left(3 \times 10^{4}\right)$ in serum-free media containing enoxaparin was added inside the inserts. Complete DMEM was added to the lower chambers as the chemoattractant. The migration plate was incubated at $37^{\circ} \mathrm{C}$ for $48 \mathrm{~h}$. Media was removed and the inserts system were immediately transferred to a clean 24-well plate containing $500 \mu \mathrm{l}$ of Calcein-AM and was incubated at $37^{\circ} \mathrm{C}$ for $1 \mathrm{~h}$. Fluorescence was measured at 494 $\mathrm{nm} / 517 \mathrm{~nm}$ from the bottom of the well.

Apoptosis assay. Cells were seeded in a 6 -well plate $\left(3 \times 10^{5} /\right.$ well) using complete DMEM and allowed to attach overnight. Media was replaced with DMEM containing 5\% FBS plus enoxaparin and doxorubicin alone or combined and incubated for $24 \mathrm{~h}$. Staurosporine (STS, $4 \mu \mathrm{M}$ ), a commonly used protein kinase inhibitor and activator of apoptosis, was used as positive control $(30,31)$. STS was dissolved in DMSO and diluted to the final concentration $(4 \mu \mathrm{M})$ to contain $0.4 \%$ DMSO. A control well for the $0.4 \%$ DMSO solvent was tested to ensure it did not induce apoptosis. Media was collected, cells were trypsinized and resuspended in $500 \mu \mathrm{l}$ binding buffer. All steps were carried out on 
ice. Annexin V-FITC $(1 \mu \mathrm{l})$ and propidium iodide (PI) $(1 \mu \mathrm{l})$ were added to cell suspensions and were incubated for 15 minutes in the dark at room temperature (RT). Samples were processed by fluorescence-activated cell sorting (FACS) flow cytometry from Millipore (Danvers, MA, USA).

Cell cycle assay. Cells were seeded in a 6 -well plate $\left(3 \times 10^{5} /\right.$ well $)$ using complete DMEM and allowed to attach overnight. Cells were serumstarved for 24 hours to synchronize them at $\mathrm{G}_{0}$ phase. Media were replaced with DMEM containing 5\% FBS plus enoxaparin and/or doxorubicin and were incubated for $24 \mathrm{~h}$. Genistein $(30 \mu \mathrm{M})$, a potent protein tyrosine kinase (PTK) inhibitor, was used as positive control to induce $\mathrm{G}_{2} / \mathrm{M}$ phase arrest in non-small cell lung cancer (32). Genistein was dissolved in ethanol and diluted to the final concentration $(30 \mu \mathrm{M})$ to contain $0.3 \%$ ethanol. A control well for the $0.3 \%$ ethanol solvent was tested to ensure it has no effect on cell cycle progression. Cells were harvested, washed with PBS and fixed with $70 \%$ ethanol for 30 min at $4^{\circ} \mathrm{C}$. Cells were re-suspended in a solution containing PBS, RNase and PI (250:1:5), then incubated at $37^{\circ} \mathrm{C}$ for $30 \mathrm{~min}$. Cell cycle analysis was performed using FACS flow cytometry (Millipore).

Western blotting assay. Protein expression of thrombin, PAR-1, PAR-2 and MMP-2 were measured using Western Blot. A549 and HepG2 cells were seeded in T-75 flask using DMEM media supplemented with $10 \%$ FBS and 1\% Pen Strep and allowed to grow to $80 \%$ confluence. To investigate the effect of enoxaparin on the activation and phosphorylation of the MAPK (ERK1/2) as well as the PI3K (Akt), A549 cells were seeded in T-25 flask $\left(7 \times 10^{5}\right.$ cells $/ 5 \mathrm{~mL} /$ flask) using DMEM media supplemented with $10 \%$ FBS and $1 \%$ Pen Strep and were allowed to attach overnight. The next day the media was replaced with fresh DMEM supplemented with $5 \%$ FBS and $1 \%$ Pen Strep, and cells were subsequently treated with final concentrations of enoxaparin for $24 \mathrm{~h}$. Cells were detached using trypsin and proteins were extracted using RIPA buffer and were then reduced with Laemmli buffer. To investigate the effect of enoxaparin on the activation of MAPK (ERK1/2) and PI3K (Akt), at the end of incubation period media was removed and cells were washed and subsequently scraped using blue loading buffer prepared as in the manufacturer's (Cell Signaling) protocol (Danvers, MA, USA). Samples were separated in 10\% tris-glycine gels and were then transferred to nitrocellulose membranes. Membranes were blocked with $5 \%$ BSA (ERK1/2 and Akt) or 5\% non-fat milk (thrombin, PAR-1, PAR-2 and MMP-2) for 1 hour. Membranes were incubated overnight with primary antibodies against thrombin $(1: 1,000)$, PAR1 $(1: 1,000)$, PAR-2 $(1: 5,000)$, MMP-2 (1:500), ERK1/2 (1:1,000), p-ERK1/2 (1:2,000), Akt $(1: 1,000)$ and p-Akt $(1: 2,000)$. Blots were incubated with secondary antibody (1:5000) for 1 hour and were visualized using LI-COR C-DiGit scanner (Lincoln, NE, USA). Band density was analyzed using Image Studio Digits Ver4.0 software (LI-COR, Lincoln, NE, USA). All protein expressions were normalized to beta-actin.

PAR-1 knockdown and PCR gene expression assay. A549 cells were seeded in a 6-well plate as previously mentioned. Opti-MEM medium was used to dilute lipofectamine reagent $(9 \mu \mathrm{l}: 150 \mu \mathrm{l})$ and PAR-1 siRNA ( $3 \mu \mathrm{l}: 150 \mu \mathrm{l})$. Diluted siRNA and Lipofectamine were mixed (1:1) and added to wells with a final concentration of $25 \mathrm{nM}$. Cells were incubated 3 days and qPCR was performed to determine knockdown efficiency. Total RNA was extracted from samples with trizol, chloroform, isopropanol then $75 \%$ ethanol. Optical density
(260/280) between 1.8-2.0 is considered pure and all RNA samples used were found to be in this range. Total RNA was reverse transcribed into cDNA. RT-PCR was performed using Applied Biosystems StepOnePlus from ThermoFisher Scientific (Waltham, MA, USA). All mRNA expressions were normalized to GAPDH. Relative fold change of gene expression was calculated using the comparative CT $\left(\Delta \Delta \mathrm{C}_{\mathrm{T}}\right)$ method.

Statistical analysis. Results are presented as mean \pm standard deviation (SD) for minimum of three independent experiments. Statistical differences were measured by student's $t$-test for two groups, or a one-way ANOVA for multiple groups, followed by Tukey's test, using GraphPad Prism7 (San Diego, CA, USA). To be considered statistically significant, $p$-Value was $<0.05$.

\section{Results}

A549 cell proliferation was evaluated after treatment with various concentrations of enoxaparin $(0.22-66 \mu \mathrm{M})$ in a reduced serum media (5\% FBS). Results demonstrated that a 24-hour enoxaparin treatment at 22, 44, and $66 \mu \mathrm{M}$ significantly inhibited cell proliferation by 10,13 , and $15 \%$, respectively, compared to control (Figure 1A). The transwell migration assay was carried out to determine the potential inhibitory effect of enoxaparin on cell migration of the A549 cells. Results showed that pretreatment with enoxaparin (22 $\mu \mathrm{M})$ for 48 hours slightly reduced cell migration and treatment with higher concentrations (44 and $66 \mu \mathrm{M}$ ) significantly reduced in vitro cell migration, a surrogate marker for metastasis, of the pulmonary adenocarcinoma A549 cells by 15 and $36 \%$, respectively, compared to negative control (Figure 1B).

Since A549 cell line expresses high levels of PAR-1 receptor while it only expresses very low levels of PAR-2 (Figure 2), we investigated the functional significance of abundant PAR-1 expression in mediating A549 cell proliferation. Data showed that treatment with $\alpha$-thrombin, a known activator of PAR-1, resulted in significant induction of cell growth by 7,13 and 20\% increase for the 2.5, 5 and 10 $\mathrm{nM}$, respectively (Figure 3). To further confirm the connection between PAR-1 and A549 cell proliferation, PAR-1 gene was silenced by siRNA. qPCR analysis demonstrated that siRNA post-transfection significantly reduced PAR-1 mRNA by $92 \%$ compared to control (data not shown). To examine whether PAR-1 knockdown would affect the proliferative behavior of A549, cell proliferation with and without PAR-1 siRNA transfection was measured. We found that in comparison to control, wells transfected with PAR-1 siRNA showed significant decrease in cell proliferation by almost $45 \%$ compared to scrambled siRNA (Figure 4A). These results suggest that PAR-1 play a vital role in mediating cell division and proliferation of the pulmonary adenocarcinoma A549 cells. To link the inhibitory capability of enoxaparin to PAR1, we examined cell proliferation of the A549 cells following PAR-1 knockdown with and without enoxaparin treatments. 

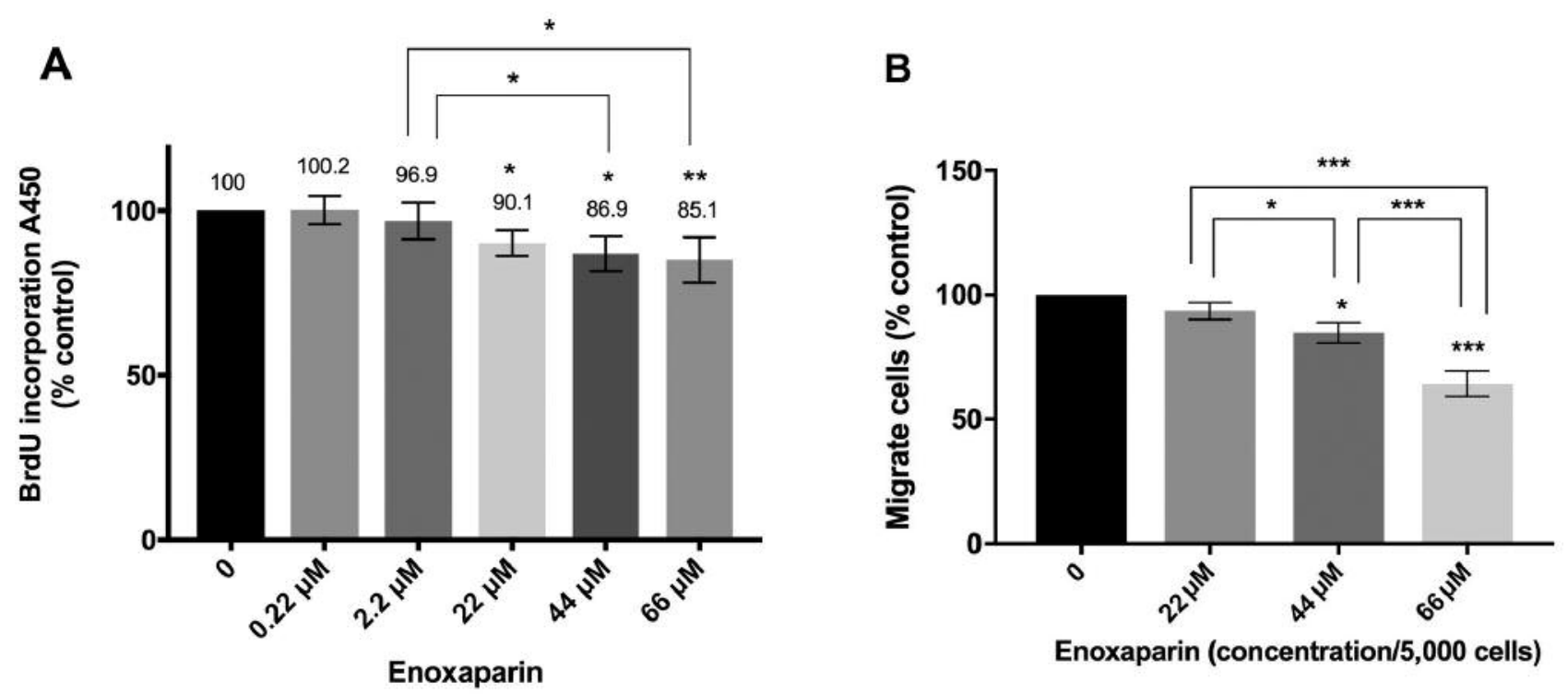

Figure 1. Inhibition of A549 cell proliferation and migration by enoxaparin. (A) BrdU ELISA assay was performed following a 24-h treatment of A549 with enoxaparin (0.22-66 $\mu \mathrm{M})$. Absorbance was measured at $450 \mathrm{~nm}$ using microplate reader SYNERGY/HT. Data are presented as a mean $\pm S . D$. of six independent experiments. $* p<0.05 * * p<0.001$ versus control group or versus respective treated groups (ANOVA). (B) Transwell migration assay was conducted following treatment with enoxaparin $(22,44$ and $66 \mu \mathrm{M})$ for 48 hours. Fluorescence was measured at $494 \mathrm{~nm} / 517 \mathrm{~nm}$ from bottom using a microplate reader SYNERGY/HT. Data are presented as a mean \pm S.D. of four independent experiments. ${ }^{*} p<0.05 * * * p<0.0001$ versus control group or versus respective treated groups (ANOVA).

We used enoxaparin concentrations that showed a significant inhibition of proliferation in our study. Our results revealed that PAR-1 knockdown not only reduced cell proliferation compared to non-siRNA treated control, but it also abolished the enoxaparin inhibitory effect under all concentrations when compared to PAR-1 siRNA treated control (Figure 4B). These results suggest that the antiproliferative effect of enoxaparin is mediated through PAR-1.

To additionally support the hypothesis that enoxaparininduced inhibition of A549 cell proliferation is mediated through a PAR-1 dependent mechanism, we examined enoxaparin's effect on PAR-1 downstream signaling cascades, specifically on the MAPK/ERK and PI3K/Akt protein expression profiles. Our data demonstrated that enoxaparin inhibited the activation of the MAPK downstream signaling protein ERK1/2, as evident by a decreased ratio of $\mathrm{p}$-ERK1/2: total ERK1/2 (Figures 5A and B). Treatment with enoxaparin $(66 \mu \mathrm{M})$ down-regulated $\mathrm{p}$-ERK1/2 expression by more than $50 \%$. Moreover, treatment with enoxaparin $(22 \mu \mathrm{M} 44$ and 66 $\mu \mathrm{M})$ down-regulated $\mathrm{p}-\mathrm{Ak}$ by about 25,70 and $80 \%$, respectively (Figures $5 \mathrm{C}$ and $\mathrm{D}$ ). These results imply that both inhibition and interference of A549 cell proliferation by enoxaparin occur through a PAR-1 dependent mechanism.

Matrix metalloproteinases (MMPs) are enzymes that degrade the extracellular matrix (ECM) and promote invasion and metastasis in malignant tumors. Several studies have indicated that at the transcriptional level, MMPs expression is regulated via the MAPK or PI3K pathways (33-36). To investigate the ability of enoxaparin to modulate MMPs expression as a consequence of suppressing the MAPK and PI3K pathways, different MMPs were measured after cells were pretreated with concentrations of enoxaparin, which significantly reduced cell migration. Enoxaparin significantly reduced MMP-2 mRNA by 65 and $75 \%$ for the 44 and $66 \mu \mathrm{M}$, respectively (Figure 6A). However, no effect was observed on MMP-1 and MMP-9 gene expression by enoxaparin (data not shown). Moreover, MMP-3 could not be detected in A549 cell line. Results also revealed that enoxaparin down-regulated MMP-2 protein levels more than $50 \%$ at $66 \mu \mathrm{M}$ (Figures $6 \mathrm{~B}$ and $\mathrm{C}$ ). Our results suggest that in vitro suppression of A549 cell migration by enoxaparin possibly occurred as a result of enoxaparin-mediated downregulation of MMP-2 expression via the inhibition of MAPK and PI3K pathways.

To assess the ability of enoxaparin to increase doxorubicin efficacy, the low concentration of $100 \mathrm{nM}$ doxorubicin was selected, based on its ability to inhibit proliferation without masking enoxaparin's effect (data not shown), and $44 \mu \mathrm{M}$ of enoxaparin was selected due to its ability to significantly inhibit both cell proliferation and migration. Our data showed that the combination of doxorubicin plus enoxaparin reduced cell proliferation of A549 by approximately $25 \%$ in 


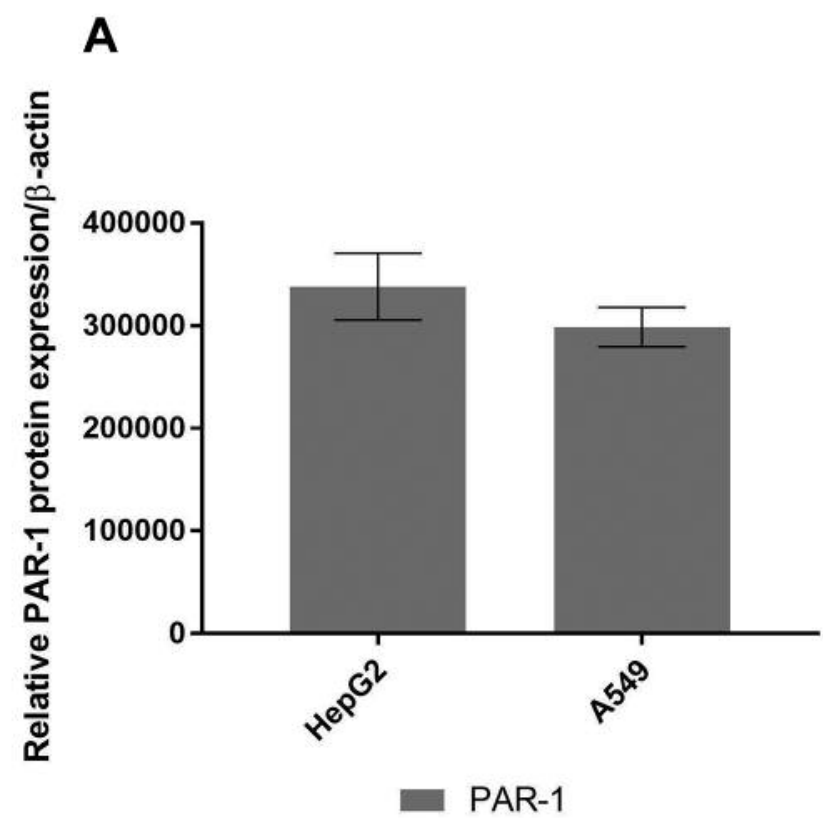

B

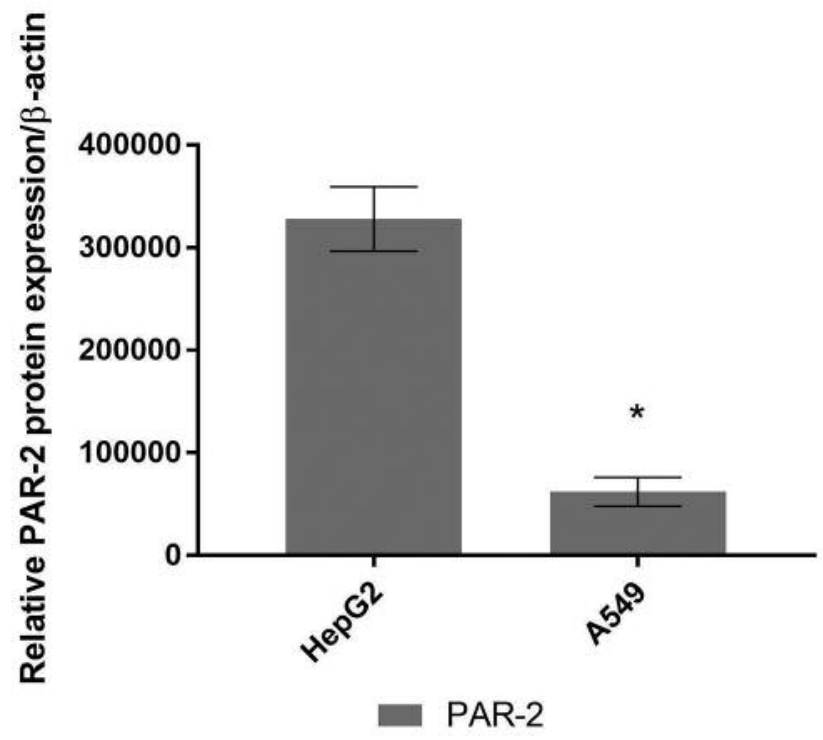

comparison to control. However, when compared to doxorubicin alone, the combined treatment inhibited cell growth by an average of $15 \%$ more (Figure 7 ). These results suggest that enoxaparin has the ability to increase the efficacy of the chemo-agent doxorubicin in A459 cells.

To explore the mechanism of doxorubicin improved inhibition of A549 cell proliferation by enoxaparin, we investigated the effect of the combination treatment on apoptosis. Administration of enoxaparin induced neither early nor late apoptosis (Figure 8). In contrast, the positive control staurosporine significantly promoted apoptosis by $43 \%$ (Figure
C

PAR-1

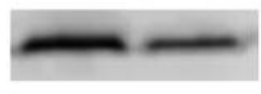

$\beta$-actin

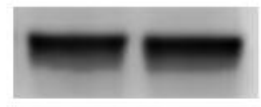

D

PAR-2

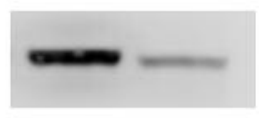

$\beta$-actin

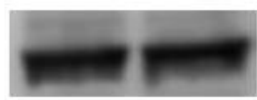

Figure 2. Semiquantitative expression levels of PAR-1 and PAR-2 proteins in A549. Western blot experiments were conducted to assess expression levels of PAR-1 ( $A$ and $C$ ) and PAR-2 ( $B$ and $D)$ in A549 and HepG2 cells. In the data shown, $A$ and $B$ are graphical representation of three independent experiments, while $C$ and $D$ are blots of one representative experiment. HepG2 cell line was used as positive control. Protein expression was normalized to $\beta$-actin. Data are presented as a mean $\pm S . D$. of three independent experiments. ${ }^{*} p<0.0001$ versus positive control group (Student's t-test).

8B). Doxorubicin induced slight apoptosis by $6 \%$ in total (Figure 8B). Doxorubicin in combination with enoxaparin (Figure 8B) significantly increased the percentage of early and late apoptotic cells by 11 and $4 \%$, respectively, compared to 4 and $2 \%$ for doxorubicin monotherapy. These data suggest that enoxaparin enhanced doxorubicin's inhibition of A549 cell proliferation through induction of apoptosis.

Furthermore, we analyzed the cell cycle status of the A549 with enoxaparin, doxorubicin and their combination treatment. Incubation with doxorubicin (Figure 9) altered the cell cycle pattern with significant increase in the number of 


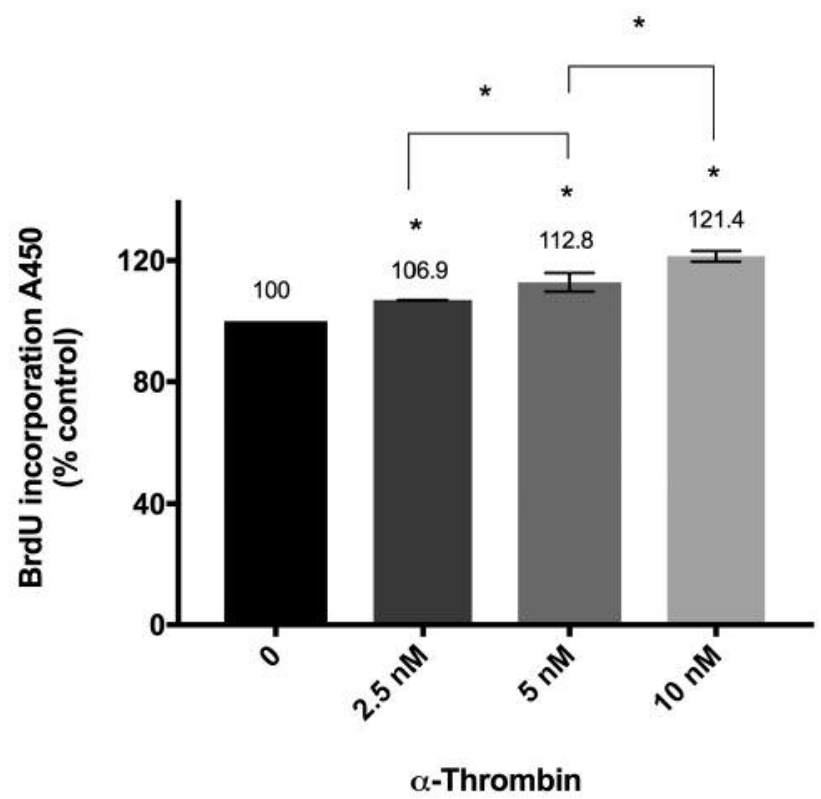

Figure 3. Effect of PAR-1 activation by thrombin on A549 cell proliferation. BrdU ELISA assay was carried out after treatment with $\alpha$-thrombin (2.5, 5 and $10 \mathrm{nM}$ ) for $24 \mathrm{~h}$ in A549 cells. Absorbance was measured at $450 \mathrm{~nm}$ using microplate reader SYNERGY/HT. Data are presented as a mean $\pm S . D$. of three independent experiments. $* p<0.0001$ versus control group or versus respective treated groups (ANOVA).

cells in $\mathrm{G}_{0} / \mathrm{G}_{1}$ phases (48.5\%) and decrease in $\mathrm{S}$ and $\mathrm{G}_{2} / \mathrm{M}$ phase $(13.9 \%$ and $37.6 \%)$. Cell cycle distribution following $44 \mu \mathrm{M}$ enoxaparin treatment was not altered compared to control. In comparison to doxorubicin alone, very similar cell distribution was observed for doxorubicin and enoxaparin cotreatment (Figure 9), suggesting that doxorubicin-induced cell cycle alteration was not affected by enoxaparin treatment.

Our data verified that in addition to its anticoagulant function the LMWH enoxaparin is capable of inhibiting two key processes of tumorigenesis, proliferation and migration, in the lung adenocarcinoma A549 cells by the interference of two major PAR-1 downstream signaling pathways, the MAPK/ERK and PI3K/Akt (Figure 10).

\section{Discussion}

Management of VTE with anticoagulant therapies in cancer patients is a challenging task, yet it is essential to decrease morbidity and mortality of patients suffering from tumorassociated thromboembolism. However, it is important to mention that the detrimental effect of VTE on the survival rate among cancer patients is not solely as a result of the thromboembolic event itself, but also of a more aggressive tumor phenotype. LMWHs have been shown to improve the survival rate of small cell lung cancer patients and those with advanced stage tumors who have a more favorable prognosis (37).
Researchers have been studying several different LMWHs' impact on lung cancer progression in vitro. Chen et al., have found that dalteparin can decrease cell viability and induce both $G_{1}$ phase arrest and apoptosis in A549 cells, effects that were due to increased levels of p21 and p27 (38). Another study using nadroparin, has demonstrated a decrease in A549 cell proliferation by inducing $\mathrm{G}_{2} / \mathrm{M}$ phase arrest due to inhibition of cyclin B1, Cdk1, and Cdc25C (39). In the melanoma (WM-266-4) and pancreatic (AsPC-1) cancer cell lines, Featherby et al., have shown that both tinzaparin and dalteparin suppresses tumor growth, invasion and vascularization (40). Also, Arab et al., have revealed a concentration- and time-dependent reduction in A549 cell proliferation by down-regulating CD44 and c-Myc expression when treated with enoxaparin (41).

In agreement with other preclinical findings for the potential anti-tumoral activities of LMWHs, the current study validated that enoxaparin can modulate A549 cell proliferation and migration in vitro. Even though the therapeutic plasma level of enoxaparin as anticoagulant clinically ranges between 1.3-2.7 $\mu \mathrm{M}$, the anticancer ability of enoxaparin in our study was detected at concentrations beyond clinical relevance, which is a limitation of our study. However, previous in vitro studies have reported that the minimum concentration of enoxaparin to inhibit proliferation and/or migration is $22 \mu \mathrm{M}(26,28,41)$, which is in the range of enoxaparin concentrations used in this study. The higher concentrations of enoxaparin necessary to obtain an antiproliferative and/or antimigratory effect in vitro may be related to either the addition of FBS in media (or other similar additives), or the fact that the hematological and immune systems are absent from in vitro systems. Therefore, further studies are necessary to determine if the therapeutic enoxaparin concentrations used for the treatment of VTE also confer an antiproliferative and/or antimigratory effect on cancer cells in vivo.

Many potential mechanisms that may explain the ability of LMWHs to interfere with tumor progression in various cancer types have been reported $(7,8,42,43)$. These proposed mechanisms fall under two major categories: i) coagulationdependent and ii) coagulation-independent. The coagulationdependent mechanisms by which LMWHs interfere with tumor development are related to their anticoagulant function through inhibition of thrombin generation. Thrombin converts fibrinogen to fibrin, and fibrin can lodge around tumor cells facilitating their survival, adhesion, and metastasis (44-46). Fibrin also provides a scaffold for angiogenesis (47). Therefore, attenuation of thrombin generation by LMWHs has the potential to reduce tumorigenesis. The coagulationindependent mechanisms are related to LMWHs' direct effect on tumor biology through alteration of PARs signaling, the fundamental link between blood coagulation and cancer pathogenesis $(10,27,48)$. Since thrombin is a PAR-1 

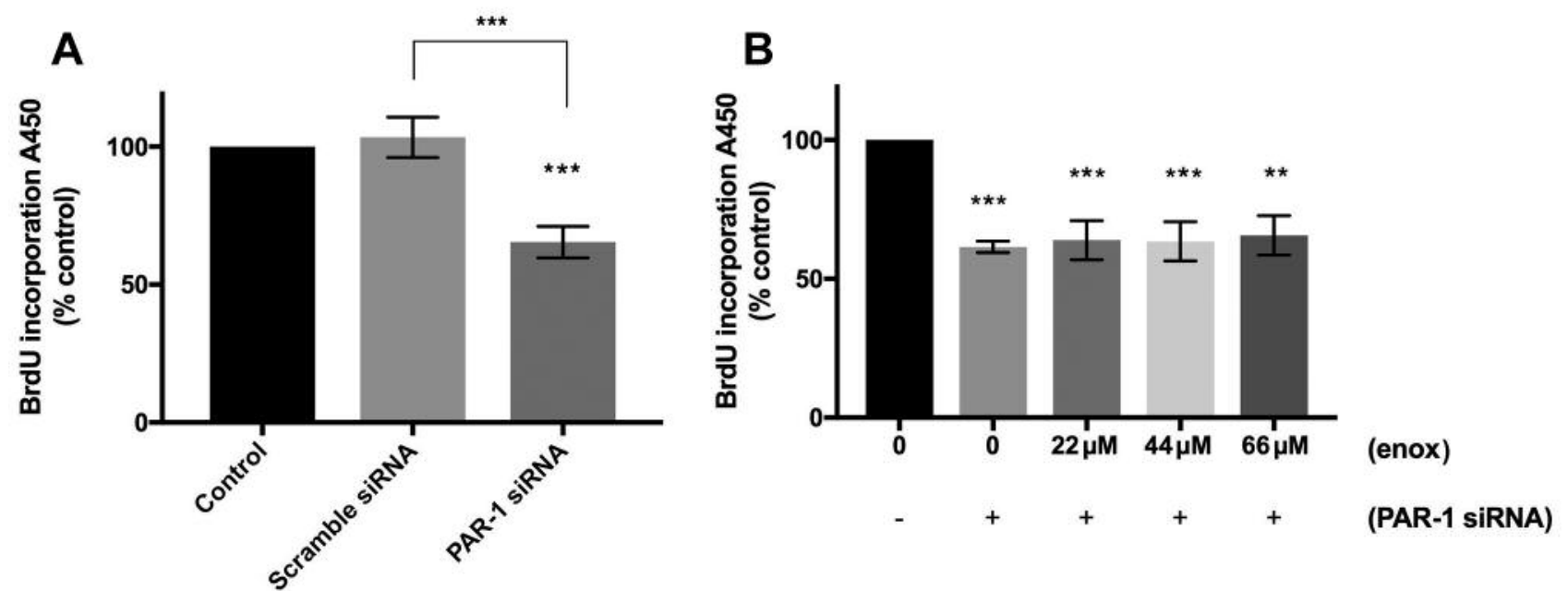

Figure 4. Effect of PAR-1 gene knockdown in the A549 cell line. BrdU ELISA assay was used to measure (A) cell proliferation of A549 cells with or without PAR-1 siRNA transfection for $72 \mathrm{~h}$. Data are presented as a mean \pm S.D. of four independent experiments. *** $<0.0001$ versus control group or versus respective treated groups (ANOVA). (B) Inhibitory effect of enoxaparin (22, 44 and $66 \mu M)$ on A549 cell proliferation after Silencing PAR-1 gene. Data are presented as a mean $\pm S D$ of three independent experiments. ${ }^{*} p=0.0001$ and $* * * p<0.0001$ versus non-siRNA treated control group (ANOVA). Absorbance was measured at $450 \mathrm{~nm}$ using the microplate reader SYNERGY/HT.

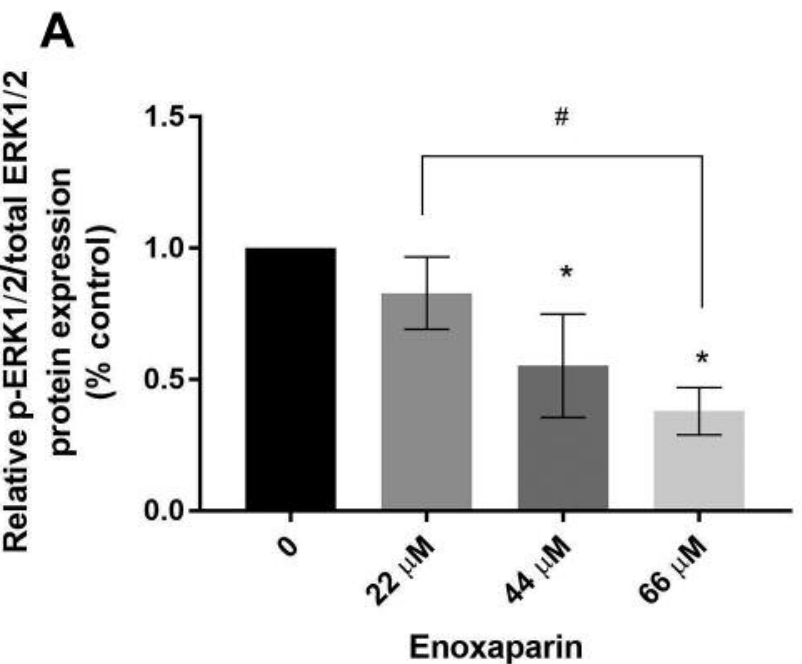

B

p-ERK1/2

Total-ERK1/2

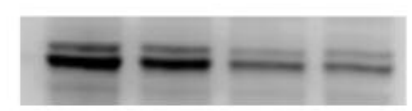

$\beta$-actin

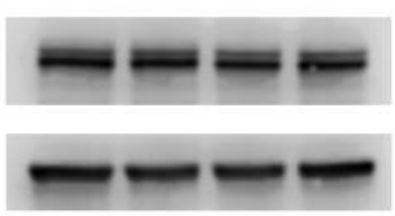

$0 \quad 22 \mu \mathrm{M} \quad 44 \mu \mathrm{M} 66 \mu \mathrm{M}$

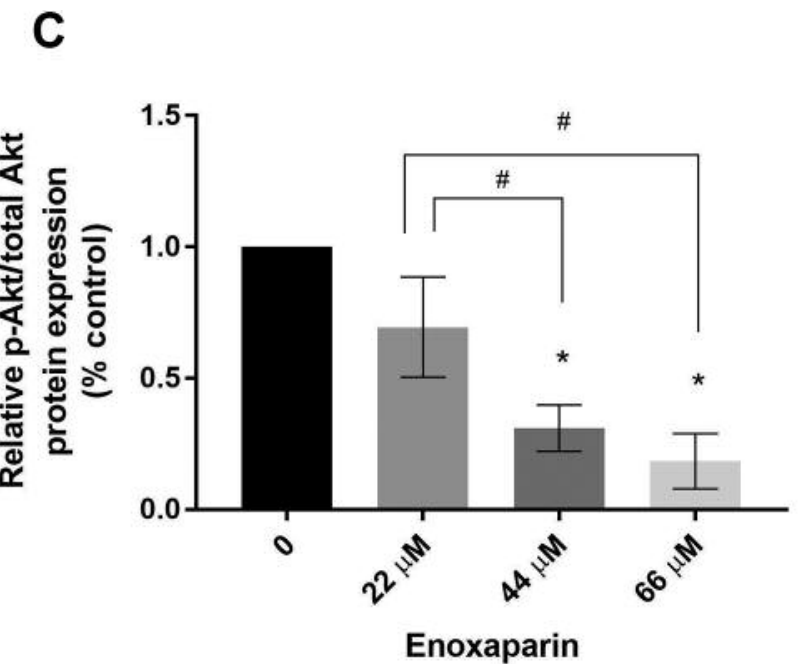

D

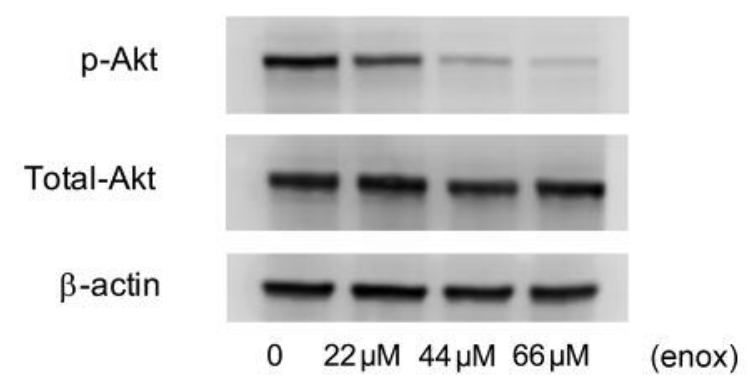

Figure 5. Effect of enoxaparin in activation of PAR-1 downstream signaling cascades. Western blot analysis was performed to examine the effect of 24-hour enoxaparin pretreatment $(22,44$ and $66 \mu M)$ on protein expression levels of p-ERK1/2: total ERK1/2 (A and B) and p-Akt: total Akt (C and $D)$. In the data shown, $A$ and $C$ are graphical representations of three independent experiments, while $B$ and $D$ are blots of one representative experiment. All protein expressions were normalized to $\beta$-actin. Data presented as a mean $\pm S D$ of three independent experiments. ${ }^{*} p<0.05$ versus control group or ${ }^{\#} p<0.05$ versus respective treated groups (ANOVA). 


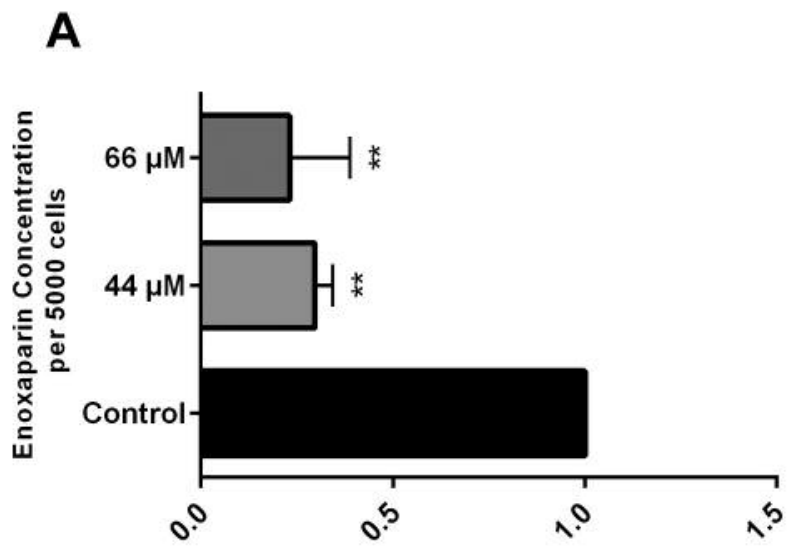

Fold change of MMP-2 Gene Expression

B

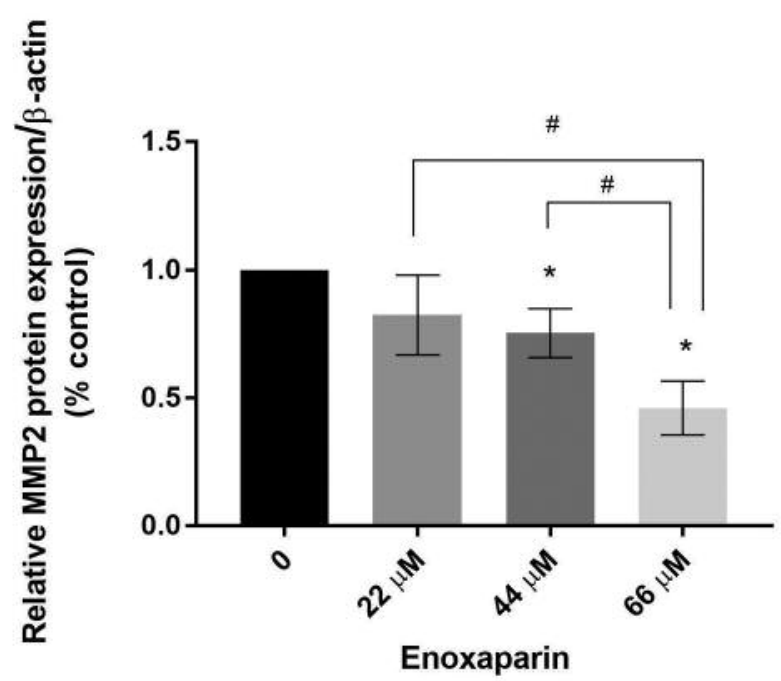

C

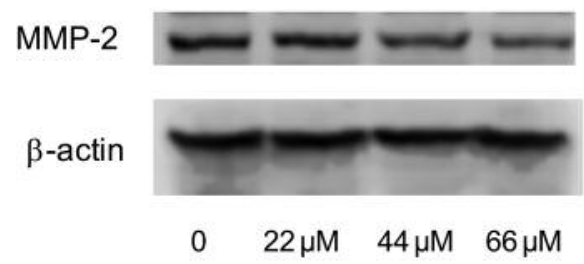

(enox)

Figure 6. Effect of enoxaparin on MMP-2 level in A549 cell line. Effect of 48 h enoxaparin treatment on (A) MMP-2 mRNA expression levels measured by $q P C R$. All reactions were measured in duplicates and $m R N A$ expressions were normalized to GADPH mRNA. Data are presented as a mean $\pm S . D$. of three independent experiments. $* * p<0.0001$ versus control group (ANOVA). B and C) MMP-2 protein expression levels measured by western blot. In the data shown, $(B)$ is the graphical representation of four independent experiments, while $(C)$ is a blot of one representative experiment. All protein expressions were normalized to $\beta$-actin. Data are presented as a mean $\pm S D$ of four independent experiments. ${ }^{*} p<0.05$ versus control group or ${ }^{\#} p<0.05$ versus respective treated groups (ANOVA).

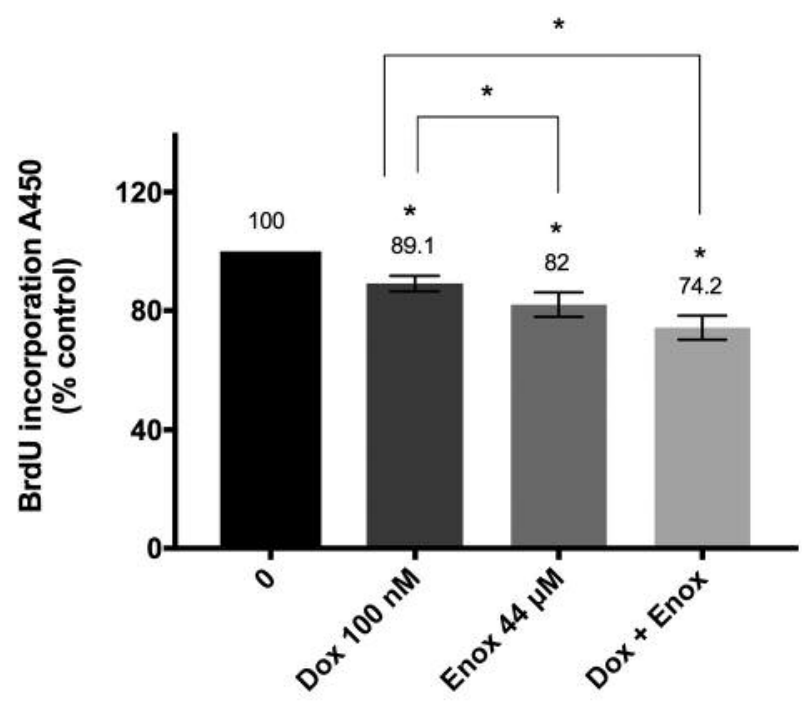

Concentration

Figure 7. Inhibition of A549 cell proliferation by enoxaparin and doxorubicin. BrdU ELISA assay was performed after treatment of the A549 cell line with $100 \mathrm{nM}$ doxorubicin or $44 \mu \mathrm{M}$ enoxaparin alone or in combination for $24 \mathrm{~h}$. Absorbance was measured at $450 \mathrm{~nm}$. Data are presented as a mean $\pm S D$ of three independent experiments. ${ }^{*} p<0.0001$ versus control group or versus respective treated groups (ANOVA).

activator, treatment with LMWHs could potentially mediate their antitumor effects by both mechanisms: i) inhibition of thrombin generation (coagulation-dependent) and ii) subsequently suppression of PARs activation and their mediated pathways (coagulation-independent). However, in our experimental conditions we found that thrombin protein levels in A549 were too low to consider the inhibition of thrombin as the mechanism responsible for enoxaparin antitumoral effects (data not shown). Nonetheless, A549 cells express high levels of PAR-1. Collectively, our findings confirmed that treatment with enoxaparin reduces cell proliferation which is likely mediated independent of thrombin inhibition, but it depends on the PAR-1 receptor by interfering with two of its major downstream transduction pathways, the MAPK/ERK and PI3K/Akt signaling.

Beside its observed activity in reducing proliferation, we found that treatment with enoxaparin has an inhibitory effect on the migration of the A549 cells. We verified that enoxaparin-mediated down-regulation of the MAPK and PI3K, as evident by their decreased active downstream effectors, p-ERK1/2 and p-Akt, resulted in reduction of MMP-2 levels and inhibition of A549 cell migration. In support of our findings, it has been reported that MMP-2 is overexpressed in multiple highly invasive malignant cancers, including A549 lung cancer cells. MMP-2 has the ability to degrade collagen IV, which is a major component of $\operatorname{ECM}(34,49,50)$. Therefore, selectively inhibiting 
A
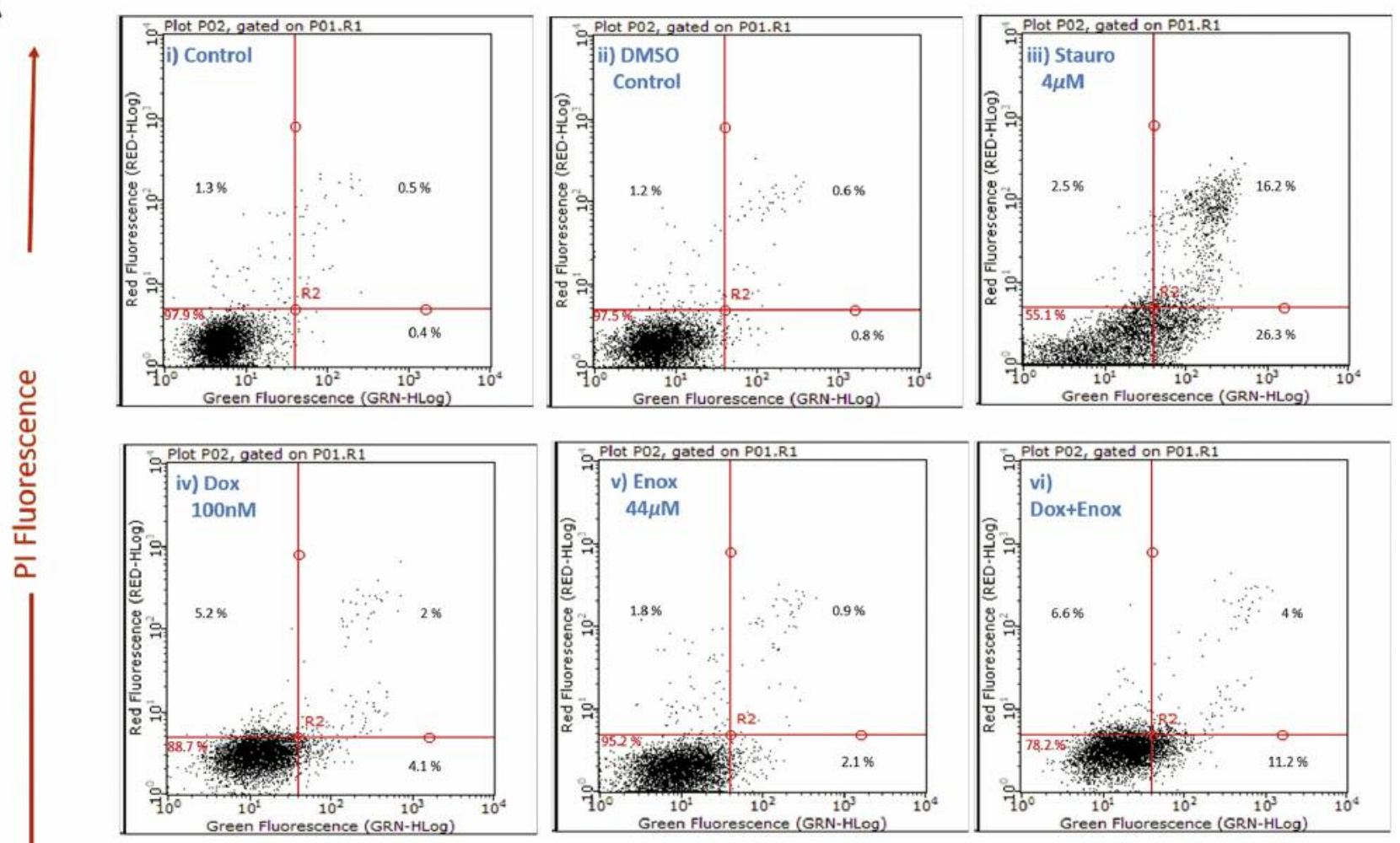

\section{Annexin V-FITC Fluorescence}

\section{B}

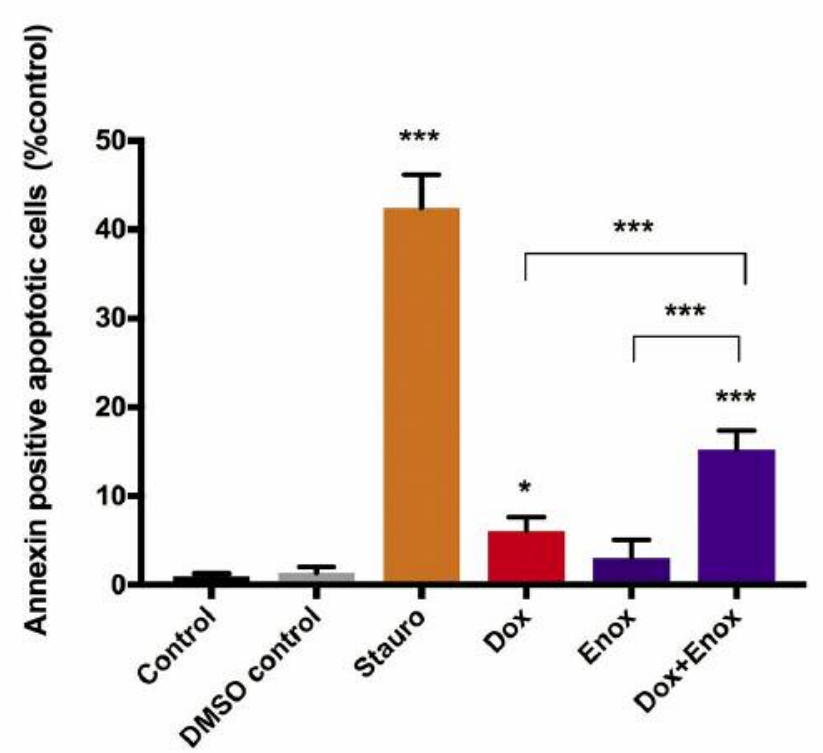

Figure 8. Induction of apoptosis in lung adenocarcinoma A549 cells. Representative scatterplots $(A)$ and graphical data $(B)$ of the effect on apoptosis after 24 h exposure to: i) control, ii) 0.4\% DMSO control, iii) $4 \mu \mathrm{M}$ staurosporine, iv) $100 \mathrm{nM}$ doxorubicin (Dox), v) $44 \mu \mathrm{M}$ enoxaparin (Enox) and vi) combination of (Dox+Enox). Apoptosis studies were carried out using Annexin-V/PI double labeling and samples were processed by a flow cytometer. Data are presented as a mean $\pm S D$ of four independent experiments. ${ }^{*} p<0.05 * * * p<0.0001$ versus control group or versus respective treated groups (ANOVA). 
A

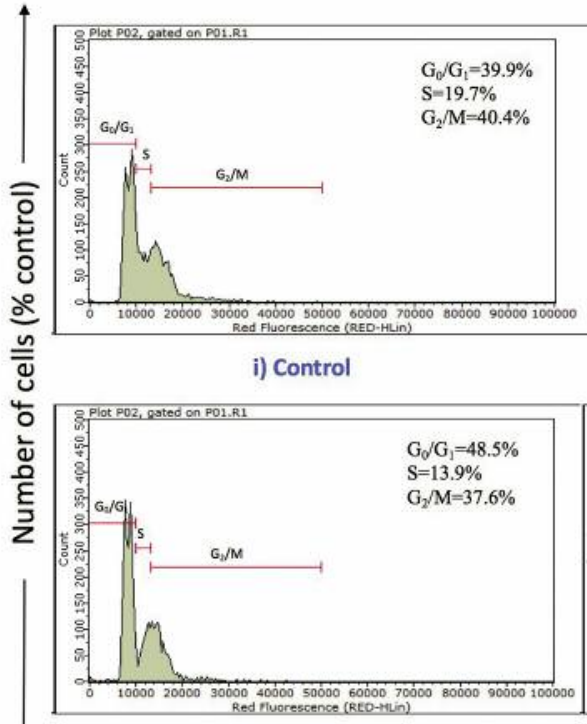

iv) Doxorubicin $100 \mathrm{nM}$

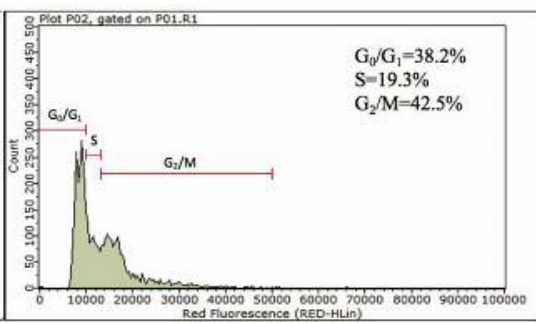

ii) Ethanol control

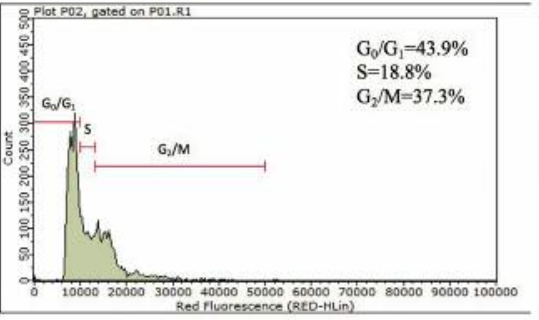

v) Enoxaparin $44 \mu \mathrm{M}$

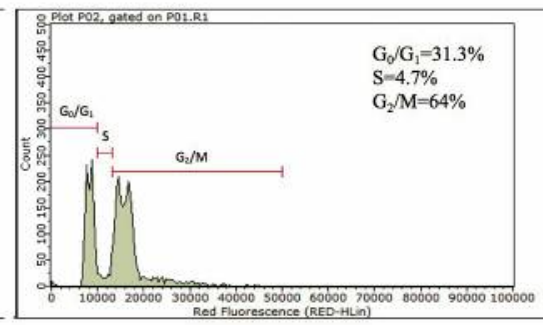

iii) Genistein $30 \mu \mathrm{M}$

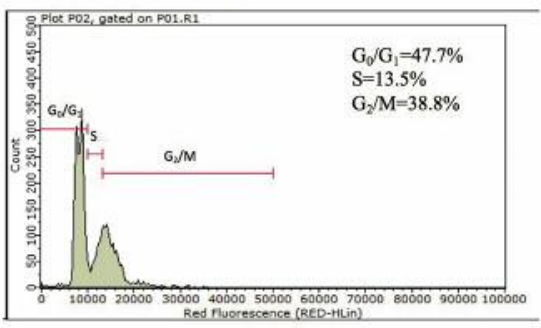

vi) Dox + Enox

DNA content

B

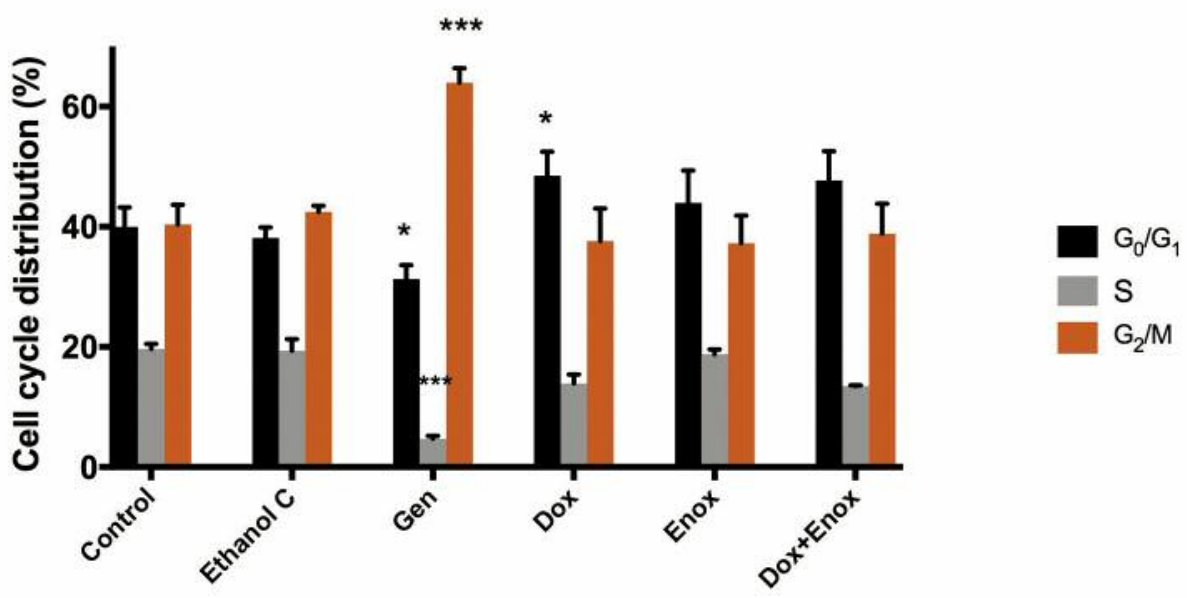

Figure 9. Cell-cycle analysis of A549 lung adenocarcinoma cell line. Representative histograms $(A)$ and graphical data $(B)$ of the effect on cellcycle progression following 24-h exposure to: i) control, ii) $0.3 \%$ ethanol control, iii) $30 \mu \mathrm{M}$ genistein, iv) $100 \mathrm{nM}$ doxorubicin (Dox), v) $44 \mu \mathrm{M}$ enoxaparin (Enox) and vi) combination of Dox+Enox. A549 cell distribution in the various cell-cycle phases was measured using PI staining as a marker for DNA content and the samples were run by a flow cytometer. Data are presented as a mean $\pm S D$ of three independent experiments. ${ }^{*}<<0.05$ $* * * p<0.0001$ versus control group (ANOVA).

MMP-2 has been shown to reduce tumor migration and invasion (51-53).

Collectively, the in vitro and in vivo studies for the antineoplastic properties of enoxaparin and other LMWHs are promising. However, they are not precisely predictive for the enhanced clinical outcomes among cancer patients, since these patients are also on a chemotherapeutic regimen before or after starting LMWH anticoagulant therapy. While most researchers have been focusing on studying the antitumoral effects of LMWHs alone, the number of studies examining the 


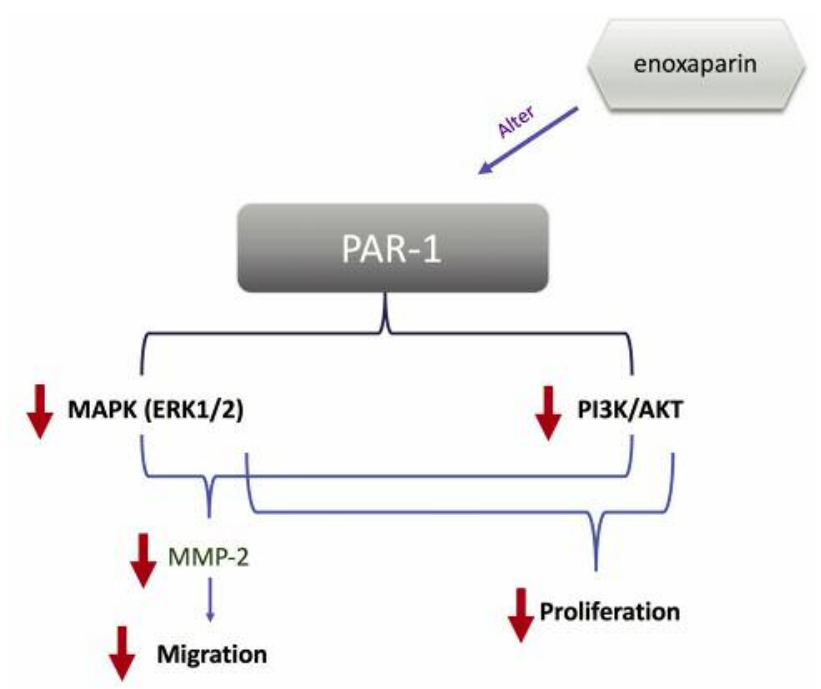

Figure 10. Proposed mechanisms of enoxaparin's anticancer effects in the A549 cell line.

therapeutic benefits of combining a LMWH with anti-cancer agent is low. Nevertheless, there are ongoing clinical and preclinical studies concerned with the benefits of adding enoxaparin to a conventional chemotherapy in various malignancies, including lung cancer (54-58). However, to our knowledge, no study has been performed to determine the combined anticancer effect(s) of combination treatment with doxorubicin and enoxaparin in the A549 cell-line. Doxorubicin is a widely used chemotherapeutic agent in the treatment of lung cancer. However, it is highly associated with the development of drug resistance $(59,60)$ and a dose-dependent cardiotoxicity $(61,62)$. Therefore, to overcome doxorubicin's drug resistance, and reduce its toxicity profile, we tested the use of a low dose of doxorubicin with enoxaparin in A549 cells. Our data demonstrate that co-treatment with enoxaparin increases doxorubicin's inhibition of cell growth by enhancing doxorubicin-induced apoptosis, although enoxaparin alone does not alter apoptosis. On the contrary, doxorubicin-mediated cell cycle alteration is not influenced by enoxaparin. Other investigators have shown conflicting results with regards to enoxaparin's effect on apoptosis and cell cycle. In agreement with the data presented in the current study, high concentration of enoxaparin $(88 \mu \mathrm{M})$ did not affect apoptosis in human colon cancer HCT- 116 cells but it induced $\mathrm{G}_{0} / \mathrm{G}_{1}$ phase arrest (63). Conversely, a different report has shown an increase in A549 cell apoptosis by enoxaparin at $44 \mu \mathrm{M}(41)$. Some factors that might influence the heterogeneity of the response to enoxaparin are: i) the experimental study design, ii) the type of cancer cells tested, cancer stage, iii) the presence of PARs receptors and thrombin expression, as well as iv) the concentration and duration of treatment. Additionally, Lean and his group have found that enoxaparin actually consists of pro- and antiproliferative oligosaccharides, and they hypothesized that even a small variation in the ratio of these saccharides can change the overall cellular response to enoxaparin (63). Unlike the sequence of their anticoagulant penta-saccharide, the exact sequence of enoxaparin (and other LMWHs) that is responsible for their antitumoral property is not yet identified. For this reason, different sources of commercially available LMWHs guarantee a predictable anticoagulant activity, but not the other potential anticancer effects. Therefore, more studies are necessary to identify the exact sequence responsible for the antitumoral activity.

In conclusion, our presented data add more evidence to the ability of enoxaparin to suppress lung cancer proliferation and migration, by down-regulating two major PAR-1 mediated pathways, the MAPK and PI3K. Clearly, enoxaparin does not have sufficient anti-cancer activity to be substituted for standard chemotherapy in cancer treatment. Nonetheless, the concept of adding enoxaparin to standard chemotherapeutic regimens might be a promising therapeutic approach, especially in the sub-population of lung cancer patients that have poor prognosis and/or are at a high risk of VTE. However, further studies are necessary to determine if the observed in vitro antiproliferative and antimigratory effects of enoxaparin are translatable in animal models of cancer.

\section{Conflicts of Interest}

The Authors declare that there are no known conflicts of interest associated with the work presented in this manuscript. Furthermore, the authors confirm that the funding provided for these studies did not influence the results in anyway.

\section{Authors' Contributions}

AA and MM conceived the idea for this project and planned the experiments. AA conducted all the experiments and drafted the manuscript under the mentorship and supervision of MM. All authors provided important scientific contributions to help shape this research, discussed the results, and reviewed the manuscript prior to submission.

\section{Acknowledgements}

The Authors thank our colleagues at the School of Pharmacy at MCPHS University-Boston for their help and support. This work was funded by MCPHS University and the Saudi Arabian Cultural Mission (SACM) and we gratefully acknowledge their financial support.

\section{References}

1 American Cancer Society. Cancer facts and figures, 2017. Available from: www.cancer.org/content/dam/cancer-org/ research/cancerfacts-and-statistics/annual-cancer-facts-and-figures/2017/cancerfacts-and-figures-2017.pdf (Last accessed on 10th May 2018). 
2 Gray E, Mulloy B and Barrowcliffe TW: Heparin and lowmolecular-weight heparin. Thromb Haemost 99(5): 807-818, 2008. PMID: 18449410. DOI: 10.1160/TH08-01-0032

3 Lyman GH, Bohlke K and Falanga A: American Society of Clinical Oncology. Venous thromboembolism prophylaxis and treatment in patients with cancer: American Society of Clinical Oncology clinical practice guideline update. J Oncol Pract 11(3): e442-444, 2015. PMID: 25873061. DOI: 10.1200/ JOP.2015.004473

4 Khorana AA, Noble S, Lee AYY, Soff G, Meyer G, O'Connell $\mathrm{C}$ and Carrier M: Role of direct oral anticoagulants in the treatment of cancer-associated venous thromboembolism: guidance from the SSC of the ISTH. J Thromb Haemost 16(9): 1891-1894, 2018. PMID: 30027649. DOI: 1111/jth.14219

5 Castelli R, Porro F and Tarsia P: The heparins and cancer: Review of clinical trials and biological properties. Vasc Med 9(3): 205-213, 2004. PMID: 15675186. DOI: 10.1191/ $1358863 \times 04 v m 566 r a$

6 Cosgrove RH, Zacharski LR, Racine E and Andersen JC: Improved cancer mortality with low-molecular-weight heparin treatment A review of the evidence. Semin Thromb Hemost 28(1): 79-87, 2002. PMID: 11885028. DOI: 10.1055/s-2002-20566

7 Mousa SA and Petersen LJ: Anti-cancer properties of lowmolecular-weight heparin: preclinical evidence. Thromb Haemost 102(2): 258-267, 2009. PMID: 19652876. DOI: 10.1160/TH08-12-0832

8 Franchini M and Mannucci PM: Low-molecular-weight heparins and cancer: Focus on antitumoral effect. Ann Med 47(2): 116-121, 2015. PMID: 25766973. DOI: 10.3109/07853890.2015.1004361

9 Agnelli G and Verso M: Management of venous thromboembolism in patients with cancer. J Thromb Haemost 9(1): 316-324, 2011. PMID: 21781268. DOI: 10.1111/j.1538-7836.2011.04346.x

10 Lima LG and Monteiro RQ: Activation of blood coagulation in cancer: implications for tumour progression. Biosci Rep 33(5): 701-710, 2013. PMID: 23889169. DOI: 10.1042/BSR20130057

11 Falanga A: Thrombophilia in cancer. Semin Thromb Hemost 31(1): 104-110, 2005. PMID: 15706482. DOI: 10.1055/s-2005863812

12 Zwicker JI, Furie BC and Furie B: Cancer-associated thrombosis. Crit Rev Oncol Hematol 62(2): 126-136, 2007. PMID: 17293122. DOI: 10.1016/j.critrevonc.2007.01.001

13 Sampson MT and Kakkar AK: Coagulation proteases and human cancer. Biochem Soc Trans 30(2): 201-207, 2002. PMID: 12023851.

14 Arora P, Ricks TK and Trejo J: Protease-activated receptor signalling, endocytic sorting and dysregulation in cancer. J Cell Sci 120(Pt 6): 921-928, 2007. PMID: 17344429. DOI: 10.1242/ jcs.03409

15 Rickles FR: Mechanisms of cancer-induced thrombosis in cancer. Pathophysiol Haemost Thromb 35(1-2): 103-110, 2006. PMID: 16855354. DOI: 10.1159/000093551

16 Macfarlane SR, Seatter MJ, Kanke T, Hunter GD and Plevin R: Proteinase-activated receptors. Pharmacol Rev 53(2): 245-282, 2001. PMID: 11356985.

17 Hansen KK, Oikonomopoulou K, Li Y and Hollenberg MD: Proteinases, proteinase-activated receptors (PARs) and the pathophysiology of cancer and diseases of the cardiovascular, musculoskeletal, nervous and gastrointestinal systems. Naunyn Schmiedebergs Arch Pharmacol 377(4-6): 377-392, 2008. PMID: 17952408. DOI: 10.1007/s00210-007-0194-2
18 Elste AP and Petersen I: Expression of proteinase-activated receptor 1-4 (PAR 1-4) in human cancer. J Mol Histol 41(2-3): 89-99, 2010. PMID: 20563836. DOI: 10.1007/s10735-010-92746

19 Nierodzik ML, Chen K, Takeshita K, Li JJ, Huang YQ, Feng XS, D'Andrea MR, Andrade-Gordon $\mathrm{P}$ and Karpatkin S: Protease-activated receptor 1 (PAR-1) is required and ratelimiting for thrombin-enhanced experimental pulmonary metastasis. Blood 92(10): 3694-3700, 1998. PMID: 9808563.

20 Even-Ram S, Uziely B, Cohen P, Grisaru-Granovsky S, Maoz M, Ginzburg Y, Reich R, Vlodavsky I and Bar-Shavit R: Thrombin receptor overexpression in malignant and physiological invasion processes. Nat Med 4(8): 909-914, 1998. PMID: 9701242.

21 Darmoul D, Gratio V, Devaud H, Lehy T and Laburthe M: Aberrant expression and activation of the thrombin receptor protease-activated receptor- 1 induces cell proliferation and motility in human colon cancer cells. Am J Pathol 162(5): 15031513, 2003. PMID: 12707033. DOI: 10.1016/S0002-9440(10) 64283-6

22 Ikeda O, Egami H, Ishiko T, Ishikawa S, Kamohara H, Hidaka $\mathrm{H}$, Mita $\mathrm{S}$ and Ogawa M: Expression of proteinase-activated receptor-2 in human pancreatic cancer: a possible relation to cancer invasion and induction of fibrosis. Int J Oncol 22(2): 295300, 2003. PMID: 12527925.

23 Nishibori M, Mori S and Takahashi HK: Physiology and pathophysiology of proteinase-activated receptors (PARs): PAR2-mediated proliferation of colon cancer cell. J Pharmacol Sci 97(1): 25-30, 2005. PMID: 15655297.

24 Queiroz KCS, Shi K, Duitman J, Aberson HL, Wilmink JW, Van Noesel CJM, Richel DJ and Spek CA: Protease-activated receptor-1 drives pancreatic cancer progression and chemoresistance. Int J Cancer 135(10): 2294-2304, 2014. PMID: 24436106. DOI: $10.1002 / \mathrm{ijc} .28726$

25 Kuderer NM, Ortel TL and Francis CW: Impact of venous thromboembolism and anticoagulation on cancer and cancer survival. J Clin Oncol 27(29): 4902-4911, 2009. PMID: 19738120. DOI: $10.1200 / \mathrm{JCO} .2009 .22 .4584$

26 Balzarotti M, Fontana F, Marras C, Boiardi A, Croci D, Ciusani $\mathrm{E}$ and Salmaggi A: In vitro study of low molecular weight heparin effect on cell growth and cell invasion in primary cell cultures of high-grade gliomas. Oncol Res 16(5): 245-250, 2006. PMID: 17294805.

27 Ichikawa J, Cole HA, Magnussen RA, Mignemi NA, Butler M, Holt GE, O'Rear L, Yuasa M, Pabla B, Haro H, Cates JM, Hamm HE, Schwartz HS and Schoenecker JG: Thrombin induces osteosarcoma growth, a function inhibited by low molecular weight heparin in vitro and in vivo: procoagulant nature of osteosarcoma. Cancer 118(9): 2494-2506, 2012. PMID: 21953059. DOI: $10.1002 / \mathrm{cncr} .26518$

28 Ellensen VS, Abrahamsen I, Lorens J and Jonung T: Effects of enoxaparin and dalteparin on proliferation and migration of patient-derived vascular smooth muscle cells. Vasa 43(2): 124131, 2014. PMID: 24627318. DOI: 10.1024/0301-1526/ a000338

29 Mousa SA, Linhardt R, Francis JL and Amirkhosravi A: Antimetastatic effect of a non-anticoagulant low-molecular-weight heparin versus the standard low-molecular-weight heparin, enoxaparin. Thromb Haemost 96(6): 816-821, 2006. PMID: 17139378. 
30 da Luz CM, Boyles MSP, Falagan-Lotsch P, Pereira MR, Tutumi HR, de Oliveira Santos E, Martins NB, Himly M, Sommer A, Foissner I, Duschl A, Granjeiro JM and Leite PE: Poly-lactic acid nanoparticles (PLA-NP) promote physiological modifications in lung epithelial cells and are internalized by clathrin-coated pits and lipid rafts. J Nanobiotechnology 15(1): 11, 2017. DOI: 10.1186/s12951-016-0238-1

31 Lakhani SA, Masud A, Kuida K, Porter GA, Booth CJ, Mehal WZ, Inayat I and Flavell RA: Caspases 3 and 7: Key mediators of mitochondrial events of apoptosis. Science 311(5762): 847851, 2006. PMID: 16469926. DOI: 10.1126/science.1115035

32 Lian F, Bhuiyan M, Li YW, Wall N, Kraut M and Sarkar FH: Genistein-induced $\mathrm{G}_{2}-\mathrm{M}$ arrest, p21WAF1 upregulation, and apoptosis in a non-small-cell lung cancer cell line. Nutr Cancer 31(3): 184-191, 1998. PMID: 9795970. DOI: 10.1080/0163558 9809514701

33 Crowe DL and Shuler CF: Regulation of tumor cell invasion by extracellular matrix. Histol Histopathol 14(2): 665-671, 1999. PMID: 10212827. DOI: 10.14670/HH-14.665

34 Westermarck $\mathrm{J}$ and Kähäri VM: Regulation of matrix metalloproteinase expression in tumor invasion. FASEB J 13(8): 781-792, 1999. PMID: 10224222.

35 Park BK, Zeng X and Glazer RI: Akt1 induces extracellular matrix invasion and matrix metalloproteinase- 2 activity in mouse mammary epithelial cells. Cancer Res 61(20): 7647-7653, 2001. PMID: 11606407.

36 Kim D, Kim S, Koh H, Yoon S, Chung AS, Cho KS and Chung $\mathrm{J}$ : Akt / PKB promotes cancer cell invasion via increased motility and metalloproteinase production. FASEB J 15(11): 1953-1962, 2001. PMID: 11532975. DOI: 10.1096/fj.01-0198com

37 Tagalakis V, Blostein M, Robinson-Cohen C and Kahn SR: The effect of anticoagulants on cancer risk and survival: Systematic review. Cancer Treat Rev 33(4): 358-368, 2007. PMID: 17408 861. DOI: 10.1016/j.ctrv.2007.02.004

38 Chen X, Xiao W, Qu X and Zhou S: The effect of dalteparin, a kind of low molecular weight heparin, on lung adenocarcinoma A549 cell line in vitro. Cancer Invest 26(7): 718-724, 2008. PMID: 18608211. DOI: 10.1080/07357900801935631

39 Carmazzi Y, Iorio M, Armani C, Cianchetti S, Raggi F, Neri T, Cordazzo C, Petrini S, Vanacore R, Bogazzi F, Paggiaro P and Celi A: The mechanisms of nadroparin-mediated inhibition of proliferation of two human lung cancer cell lines. Cell Prolif 45(6): 545-556, 2012. PMID: 23106301. DOI: 10.1111/j.13652184.2012.00847.x

40 Featherby S, Xiao YP, Ettelaie C, Nikitenko LL, Greenman J and Maraveyas A: Low molecular weight heparin and direct oral anticoagulants influence tumour formation, growth, invasion and vascularisation by separate mechanisms. Sci Rep 9(1): 6272, 2019. PMID: 31000751. DOI: 10-1038/s41598-019-42738-1

41 Arab WA, Kotb R, Sirois M and Rousseau E: Concentration- and time-dependent effects of enoxaparin on human adenocarcinomic epithelial cell line A549 proliferation in vitro. Can J Physiol Pharmacol 89(10): 705-711, 2011. PMID: 21905823. DOI: $10.1139 / \mathrm{y} 11-068$

42 Pineo $G$ and Hull R: Effects of anticoagulants on cancer: Heparins. Cancer Treat Res 148: 259-275, 2009. PMID: 19377929. DOI: $10.1007 / 978-0-387-79962-9 \_15$

43 Borsig L: Heparin as an inhibitor of cancer progression. Prog Mol Biol Transl Sci 93(C): 335-349, 2010. PMID: 20807651. DOI: $10-1016 / \mathrm{S} 1877-1173(10) 93014-7$
44 Nagy JA, Brown LF, Senger DR, Lanir N, Van De Water L, Dvorak AM and Dvorak HF: Pathogenesis of tumor stroma generation: a critical role for leaky blood vessels and fibrin deposition. BBA Rev Cancer 948(3): 305-326, 1989. PMID: 2465781. DOI: 10-1016/0304-419x(89)90004-8

$45 \mathrm{Hu}$ L, Lee M, Campbell W, Perez-Soler R and Karpatkin SL: Role of endogenous thrombin in tumor implantation, seeding, and spontaneous metastasis. Blood 104(9): 2746-2751, 2004. PMID: 15265791. DOI: 10.1182/blood-2004-03-1047

46 Palumbo JS, Kombrinck KW, Drew AF, Grimes TS, Kiser JH, Degen JL and Bugge TH: Fibrinogen is an important determinant of the metastatic potential of circulating tumor cells. Blood 96(10): 3302-339, 2000. PMID: 11071621.

47 Van Hinsbergh VW, Collen A and Koolwijk P: Role of fibrin matrix in angiogenesis. Ann N Y Acad Sci 936: 426-437, 2001. PMID: 11460496. DOI: 10.1111/j.1749-6632.2001.tb03526.x

48 Wojtukiewicz MZ, Hempel D, Sierko E, Tucker SC and Honn $\mathrm{KV}$ : Protease-activated receptors (PARs)-biology and role in cancer invasion and metastasis. Cancer Metastasis Rev 34(4): 775796, 2015. PMID: 26573921. DOI: 10.1007/s10555-015-9599-4

$49 \mathrm{Li} \mathrm{X}$ and Tai H-H: Increased expression of matrix metalloproteinases mediates thromboxane A2-induced invasion in lung cancer cells. Curr Cancer Drug Targets 12(6): 703-715, 2012. PMID: 22515524.

50 Kleiner DE and Stetler-Stevenson WG: Matrix metalloproteinases and metastasis. Cancer Chemother Pharmacol 43(Suppl): S42-51, 1999. PMID: 10357558.

51 Chien CS, Shen KH, Huang JS, Ko SC and Shih YW: Antimetastatic potential of fisetin involves inactivation of the $\mathrm{PI} 3 \mathrm{~K} / \mathrm{Akt}$ and JNK signaling pathways with downregulation of MMP-2/9 expressions in prostate cancer PC-3 cells. Mol Cell Biochem 333(1-2): 169-180, 2010. PMID: 19633975. DOI: 10.1007/s11010-009-0217-z

52 Lee H, Kim JS and Kim E: Fucoidan from seaweed fucus vesiculosus inhibits migration and invasion of human lung cancer cell via PI3K-Akt-mTOR pathways. PLoS One 7(11): e50624, 2012. PMID: 23226337. DOI: 10.1371/journal.pone. 0050624

53 Zhang L, Wang H, Zhu J, Ding K and Xu J: FTY720 reduces migration and invasion of human glioblastoma cell lines via inhibiting the PI3K/AKT/mTOR/p70S6K signaling pathway. Tumour Biol 35(11): 10707-10714, 2014. PMID: 25070489. DOI: $10.1007 / \mathrm{s} 13277-014-2386-\mathrm{y}$

54 Robert F, Busby E, Marques MB, Reynolds RE and Carey DE: Phase II study of docetaxel plus enoxaparin in chemotherapynaive patients with metastatic non-small cell lung cancer: preliminary results. Lung Cancer 42(2): 237-245, 2003. PMID: 14568692.

55 Seeholzer N, Thürlimann B, Köberle D, Hess D and Korte W: Combining chemotherapy and low-molecular-weight heparin for the treatment of advanced breast cancer: results on clinical response, transforming growth factor-beta 1 and fibrin monomer in a phase II study. Blood Coagul Fibrinolysis 18(5): 415-423, 2007. PMID: 17581315. DOI: 10.1097/MBC.0b013e3281139c1d

56 Riess H, Pelzer U, Opitz B, Stauch M, Reitzig P, Hahnfeld S, Müller L, Stieler J, Dörken B and Oettle H: A prospective, randomized trial of simultaneous pancreatic cancer treatment with enoxaparin and chemotherapy: Final results of the CONKO-004 trial. J Clin Oncol 28(15_suppl): 4033, 2010. DOI: 10.1200/jco.2010.28.15_suppl.4033 
57 Niu Q, Wang W, Li Y, Ruden DM, Wang F, Li Y, Wang F, Song $\mathrm{J}$ and Zheng $\mathrm{K}$ : Low molecular weight heparin ablates lung cancer cisplatin-resistance by inducing proteasome-mediated ABCG2 protein degradation. PLoS One 7(7): e41035, 2012. PMID: 22844424. DOI: 10.1371/journal.pone.0041035

58 Pan Y, Li X, Duan J, Yuan L, Fan S, Fan J, Xiaokaiti Y, Yang H, Wang $\mathrm{Y}$ and Li X: Enoxaparin sensitizes human non-small-cell lung carcinomas to gefitinib by inhibiting DOCK1 expression, vimentin phosphorylation and Akt activation. Mol Pharmacol 87(3): 378-390, 2015. PMID: 25488183. DOI: 10.1124/ mol.114.094425

59 Wang Y, Zhang H, Hao J, Li B, Li M and Xiuwen W: Lung cancer combination therapy: co-delivery of paclitaxel and doxorubicin by nanostructured lipid carriers for synergistic effect. Drug Deliv 23(4): 1398-1403, 2016. PMID: 26079530. DOI: $10.3109 / 10717544.2015 .1055619$

60 Lv S, Tang Z, Li M, Lin J, Song W, Liu H, Huang Y, Zhang Y and Chen X: Co-delivery of doxorubicin and paclitaxel by PEGpolypeptide nanovehicle for the treatment of non-small cell lung cancer. Biomaterials 35(23): 6118-6129, 2014. PMID: 24794923. DOI: $10.1016 /$ j.biomaterials.2014.04.034
61 Rivankar S: An overview of doxorubicin formulations in cancer therapy. J Cancer Res Ther 10(4): 853-858, 2014. PMID: 25579518. DOI: 10.4103/0973-1482.139267

62 Waterhouse DN, Tardi PG, Mayer LD and Bally MB: A comparison of liposomal formulations of doxorubicin with drug administered in free form: changing toxicity profiles. Drug Saf 24(12): 903-920, 2001. PMID: 11735647. DOI: $10.2165 /$ 00002018-200124120-00004

63 Lean QY, Patel RP, Stewart N, Sohal SS and Gueven N: Identification of pro- and anti-proliferative oligosaccharides of heparins. Integr Biol (UK) 6(1): 90-99, 2014. PMID: 24310794. DOI: $10.1039 / \mathrm{c} 3 \mathrm{ib} 40206 \mathrm{a}$
Received June 4, 2019

Revised July 25, 2019

Accepted July 30, 2019 